THE KURUME MEDICAL JOURNAL Vol. 4, No. 2, 1957

\title{
PURIFICATION AND CONCENTRATION OF GDVII STRAIN OF MOUSE ENCEPHALOMYELITIS VIRUS II. REPORT. PURIFICATION AND CONCENTRATION OF GDVII VIRUS BY MEANS OF RED CELL STROMA
}

\author{
YOH NAKAGAWA AND MASAHIRO NAKAMURA \\ Department of Microbiology, Kurume University School of Medicine, \\ Kurume-shi, Japan
}

Since a procedure of purification and concentration of virus by means of adsorption to and elution from erythrocytes is a simple and effective method, some experiments of purification of pneumotropic and neurotropic viruses capable of hamegglutination have been made by this method. The studies on purification and concentration of the GDVII strain of mouse encephalomyelitis virus were described by Lahelle and Ward, (1) and Nakagawa and Nakamura (2) (3) in recent years. However, that the concentration of the virus by this procedure did not produce satisfactory yields of virus because of hemolysis appearing in the process of concentration of the virus by elution from erythrocytes, and that the combination of the methods by means of methanol and acetone precipitation at low temperature with the method of hemagglutination was attempted for obtaining more satisfactory results, were reported in previous papers (2) (3).

The purpose of the present paper is to report the research on further more effective method by means of adsorption to and elution from the red cells stroma (4) which are capable of adsorption of viruses.

\section{MATERIALS AND METHODS}

Virus The GDVII virus used was maintained by intracerebral passages in adult mice in this laboratory. Brains were removed from exsanguinated mice shortly after the appearance of signs indicating infection of the central nervous system, and a ten per cent suspension was made up in saline solution $(\mathrm{pH} 7.0$ ), and were removed the coarse particles by centrifugation at $3000 \mathrm{RPM}$ for 5 minutes. These crude suspensions were employed promptly after preparation as the starting materials.

Stroma (5) A part of five per cent saponin (Merck) solution added to nine part of ten per cent human group 0 erythrocytes suspension with the saline solution, and after hemolysis occurred, the stroma suspension were made by three times washing and resuspending with saline solution.

Purification procedure of virus. The crude suspension was mixed with the equal 
volume of human Group 0 erythrocytes suspension in saline solution. After the agitation every five minutes for one hour in the cold, the mixed solution was allowed to stand at $4 \mathrm{C}$ overnight, and was separated the supernatant fluid from erythrocytes by centrifugation at $3000 \mathrm{RPM}$ for 15 minutes. One third of the original volume of saline solution as eluant was added to erythrocytes sedimented, and was kept $37 \mathrm{C}$ with occassional agitation for one hour. The supernatant fluid separated by centrifugation at 3000 RPM for 15 minutes was mixed with the equal volume of stroma suspension, and after occassional agitation for one hour in the cold, the mixture was allowed to stand at $4 \mathrm{C}$ over night. After centrifugation at $3000 \mathrm{RPM}$ for 15 minutes, the Sörensen buffer solution $(\mathrm{pH} \mathrm{7.0)}$ ) as eluant was added to the stroma sedimented which might adsorb the virus particles, and elution of virus was carried out by keeping at $37 \mathrm{C}$ for one hour. The stroma was centrifuged off at $9000 \mathrm{RPM}$ for 20 minutes in the cold, and the supernatant fluid was obtained as the final product.

Hemagglutination procedure (6). Briefly, serial 2-fold dilution of the suspension prepared tested in saline solution $(\mathrm{pH} 7.0)$ and $0.3 \%$ human Group $\mathrm{O}$ erythocytes suspension were mixed. The agglutination were performed at $4 \mathrm{C}$. Readings were made after 2 hours by observing the agglutination pattern with the naked eye and taking the endpoint as the highest dilution.

Infectivity. Titration of the content of the virus in the materials was expressed as $50 \%$ infectivity endpoint $\left(\mathrm{LD}_{50}\right)$ by the inoculation of the materials into mice by the intracerebral route.

Nitrogen content. The nitrogen content of all materials was measured by the micro-K jeldahl method.

\section{EXPERIMENTAL}

Determination of dosage of stroma and time of adsorption in the adsorption and elution of virus procedure with stroma. One, five and ten per cent stroma suspension were prepared, and each suspension was added to the equal volume of the crude virus suspension, and then was kept in the cold for 2, 4 or 18 hours. The data of determination of the effect for virus adsorption to the stroma by measurement of hemagglutination titer of supernate after centrifugation are shown in Table 1 . The results indicated that the greater amounts of virus particles in the starting materials were adsorbed to the stroma during the adsorption procedure for 18 hours in the cold, but that the adsorption of virus to the stroma suspension was less effective than that of virus to the erythrocytes. Therefore, a twenty per cent of the stroma suspension was employed for the following experiments. 
TABLE 1

Relationship between dosage of stroma and time of adsorption in the GDVII virus-hemagglutination procedure

\begin{tabular}{c|c|c|c}
\hline \multirow{2}{*}{ Stroma } & Time of adsorption & \multicolumn{2}{|c}{ Hemagglutination titer } \\
\cline { 2 - 3 } & 2 & Crude & Stroma supernate \\
\hline 1 & 4 & 2,560 & 128 \\
1 & 18 & 2,560 & 80 \\
1 & 2 & 2,560 & 80 \\
\hline 5 & 4 & 2,560 & 640 \\
5 & 18 & 2,560 & 80 \\
5 & 2 & 2,560 & 80 \\
\hline 10 & 4 & 2,560 & 640 \\
10 & 18 & 2,560 & 80 \\
10 & & 2,560 & 80 \\
\hline
\end{tabular}

Purification and concentration of GDVII virus by means of adsorption to and elution from erythrocytes and stroma. In the first step, the virus was adsorbed to the human $\mathrm{O}$ Group erythrocytes, and was eluted from erythrocytes by saline solution in the volume which did not occur hemolysis, and finally the virus eluted into the saline solution was adsorbed to and eluted from the twenty per cent stroma suspension.

The results obtained are shown in Table 2. The studies on the concentration of virus in the one two-hundredth of the original volume were attempted in this experiment. It is obvious that the concentration procedure of virus by stroma is more

TABLE 2

Purification of GDVII-virus by means of adsorption and elution with exythrocytes and stroma

\begin{tabular}{|c|c|c|c|c|c|c|c|c|c|}
\hline \multirow{2}{*}{$\begin{array}{l}\text { Exp. } \\
\text { No. }\end{array}$} & \multirow{2}{*}{ 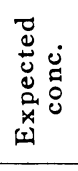 } & \multicolumn{2}{|l|}{$\mathrm{H}$} & \multirow{2}{*}{$\begin{array}{l}0 \\
0 \\
D \\
0 \\
0 \\
0 \\
0 \\
0\end{array}$} & \multicolumn{2}{|c|}{$\mathrm{r} \mathrm{N}$ per $\mathrm{ml}$} & \multirow{2}{*}{ 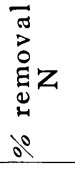 } & \multicolumn{2}{|c|}{ 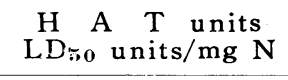 } \\
\hline & & Crude & Purified & & Crude & Purified & & Crude & Purified \\
\hline 1 & 1 & 256 & 256 & 1 & 1484.0 & 117.6 & 92.1 . & $1 \times 10^{2 \cdot 55}$ & $1 \times 10^{3.64}$ \\
\hline 2 & 20 & 4096 & 4096 & 16 & 1078.0 & 8.4 & 99.2 & $1 \times 10^{2 \cdot 96}$ & $1 \times 10^{5 \cdot 99}$ \\
\hline 3 & 100 & 256 & 524288 & 2048 & 981.4 & 1.8 & 99.8 & $1 \times 10^{2: 72}$ & $1 \times 10^{8 \cdot 76}$ \\
\hline 4 & 200 & 256 & 2096152 & 8192 & 909.1 & 1.6 & 99.8 & $1 \times 10^{2 \cdot 75}$ & $1 \times 10^{9.42}$ \\
\hline 5 & 100 & 256 & 1048576 & 4096 & 991.2 & 5.6 & 99.5 & $1 \times 10^{2 \cdot 71}$ & $1 \times 10^{8 \cdot 57}$ \\
\hline 5 & 100 & $10^{-5 \cdot 24}$ & $10^{-5 \cdot 62}$ & & 991.2 & 5.6 & 99.5 & $10^{-6 \cdot 944}$ & $10^{-9.571}$ \\
\hline$\underset{\text { brain }}{\text { Normal }}$ & 100 & 0 & 0 & $\mathbf{0}$ & 918.4 & 28.0 & 97.0 & 0 & 0 \\
\hline
\end{tabular}


effective than that of erythrocytes for the removal of total nitrogen in the final product, that is, the former is able to concentrate the virus in more approximately $1 \times 10^{6}$ hemagglutinating units per $\mathrm{mg} \mathrm{N}$, and $1000-$ fold $\mathrm{LD}_{50}$ per $\mathrm{mg} \mathrm{N}$ than that of the original materials. These results are unable to obtain by adsorption to and elution from erythrocytes procedure because of hemolysis.

\section{DISCUSSION}

In previous reports (2) (3), the studies on purification and concentration of GDVII virus by means of hemagglutination were described. The results of the experiments indicated that the purification of the virus by means of adsorption and elution produce with erythrocytes was very effective method, however, that the concentration of the virus by this procedure did not produce satisfactory yields of virus because of hemolysis in the concentrating elution of the virus from erythrocytes. To avoid this hemolysis, various kinds of eluants of the virus from erythrocytes were examined, but unfortunately it was confirmed that all solutions employed could not avoid the hemolysis in the concentration procedure of virus, for instance, in the case of 10 -fold concentration of virus by elution into one tenth volume of saline, hemolysis occurred without exception, and then the nitrogen content in the final products increased. Therefore, the concentration method by means of methanol and acetone precipitation at low temperature was employed for obtaining the good yield of virus in the purified material.

In the present paper, a very simple method of purification and concentration of virus which utilized the virus hemagglutinative capacity only, without the precipitation procedure, was reported. As there was an obstacle of hemolysis for getting good yield of virus in the final product in previous experiments, the stroma which has not consideration with hemolysis was employed in the present experiments.

The data of these experiments demonstrated the hemagglutination titer of the original crude suspension, in the experiment No. 4, was 256 and the titer of the final concentrated preparation was $2,096,152$ with reduction of 99.8 per cent of the nitrogen, as well as in the experiment No. 5 , the $\mathrm{LD}_{50}$ of the crude material was $10^{-5.24}$ and that of the final product was $10^{-5.62}$ with reduction of 99.5 per cent of the nitrogen. In other words, the final product contained $9.571\left(-\log \mathrm{LD}_{50}\right)$ units per $\mathrm{mg} \mathrm{N}$ while the crude material contained $6.944\left(-\log \mathrm{LD}_{50}\right)$ units per $\mathrm{mg} \mathrm{N}$, i.e. it is indicated that virus is concentrated in approximately 1000-fold per $\mathrm{ml}$ with the removal of non-virus protein from the starting material. Lahelle and Ward (1) attempted the purification of the GDVII virus by meafis of adsorption to and elution from stroma corresponding to 10 per cent red cells, and got more eff ective yields of virus than that of 
hemagglutination procedure. However, they did not make an experiment of concentration of virus. Homma et al (7) demonstrated that the chicken red cell stroma is suitable to adsorb and elute the influenza virus for production of influenza viral vaccine, and that the capacity of the stroma to adsorb and elute the influenza virus was heat resistant ( $100 \mathrm{C}$ for 30 minutes) and was unchanged when stored at $4 \mathrm{C}$ as long as 4 weeks.

It may be emphasized, therefore, that a procedure by means of adsorption to and elution from stroma is a simple, effective, and valuable method for the purification and concentration of virus capable of hemagglutination. However, as the removal of normal components (8) contained in the normal brains which have the dispute in the case of purification and identification of virus by observing the electron micrographs has not been made by this method, the following experiments, in future, should develop to solve the problems concerning the normal components.

\section{SUMMARY}

Purification and concentration of the GDVII strain of mouse encephalomyelitis virus by means of adsorption and elution with red cell stroma was attempted. This method is a simple, effective and useful procedure in high concentration of virus without consideration of hemolysis.

\section{REF ERENCES}

1. Lahelle, O. and Ward, G. T.: Purification and concentration of mouse encephalomyelitis virus by hemagglutination. J. Imm. Vol. 67, 75-81; 1951.

2. Nakagawa, Y. and Nakamura, M.: Purification and concentration of GDVII strain of mouse encephalomyelitis virus by means of ether extraction, hemagglutination, and methanol and acetone precipitation. I. Report. Kurume Med. J., Vol. 2, 32-41, 1955.

3. NaKagaiva, Y. and NaKamura, M.: Purification and concentration of GDVII strain of mouse encephalomyelitis virus. I. Report. Virus, Vol. 5, 271-277, 1955.

4. Yamamoto, S. and FukUmi. H.: Studies on the hemagglutination with influenza virus and its application. VI Report. Medicine and Biology, Vol. 12. 64-66 1948.

5. Higashi, N., WaKizaKa, K., and Mizukawa I, : Studies on the erythrocytes under electron microscope. J. of Electron Microscopy, Vol. 1, 32-35, 1950.

6. Lahelle, H. and Horsfall, F. L.: Hemagglutination with the GDVII strain of mouse encephalomyelitis virus. Proc. Soc. Exper. Bipl. \& Med., Vol. 71, 713-718, 1949.

7. Homma, S., Nagaki, D., and Uchiyama. T.: Studies on influenza virus. 1. Adsorption and elution of the influenza virus with chicken red cell stroma. Kitasato Arch of Exp. Med., Vol. 26, 195-198, 1953.

8. Taylor, A. R., Sharp, D. G., Beard, D., and Beard, J. W.: Isolation and properties of 
a macromolecular component of normal chick embryo tissue. J. Inf. Diseases. Vol. 71, $115-126,1942$. 